\title{
Changes in Cropland Area in the United States and the Role of CRP
}

\author{
Nathan P. Hendricks* $\quad$ Emrah Er ${ }^{\dagger}$
}

January 2018

\begin{abstract}
An understanding of the main drivers of land-use change is critical for policy recommendations that aim to meet the challenge of food and environmental security over the coming decades. Here we show that agricultural policy exerts substantial influence on cropland area in the United States through administration of the Conservation Reserve Program (CRP). Looking at changes in the CRP over time and an understanding of how the program is managed suggest that the government adjusts enrolled acres in response to changing market conditions to achieve supply management objectives and due to budgetary reasons. The projected decrease of 12.8 million acres of CRP from 2007 to 2017 is estimated to decrease corn and soybean prices by $8.9 \%$ and $5.4 \%$, while a hypothetical return to $2007 \mathrm{CRP}$ acreage is estimated to increase corn and soybean prices by $12.0 \%$ and $7.3 \%$.
\end{abstract}

Keywords: land-use change, cropland expansion, grassland loss, agricultural policy

(C) 2018. This manuscript version is made available under the CC-BY-NC-ND 4.0 license http://creativecommons.org/licenses/by-nc-nd/4.0//

${ }^{*}$ Department of Agricultural Economics, Kansas State University, Manhattan, KS 66506. nph@ksu.edu

${ }^{\dagger}$ Department of Agricultural Economics, Kansas State University, Manhattan, KS 66506. 
"If you can tell me where prices are, and more importantly, where they are trending around the time Congress begins the farm bill debate, then I can usually give you some direction where they are going to go with the farm bill."1

- Chuck Conner, CEO of the National Council of Farmer Cooperatives

\section{Introduction}

The expansion of cropland in the U.S. following the spike in crop prices in 2008 has garnered substantial attention. Conversions of grassland to cropland are especially important because these conversions have negative environmental impacts through carbon emissions (Gebhart et al. 1994; Fargione et al. 2008; Gelfand et al. 2011), biodiversity loss (Herkert 2007; Meehan, Hurlbert, and Gratton 2010), water quality degradation (Das et al. 2004; Donner and Kucharik 2008; Keeler and Polasky 2014), and soil erosion (Pimentel et al. 1995). While higher crop prices undoubtedly cause farmers to expand cropland by affecting the relative profitability of cropland, we argue in this paper that it is also important to recognize the impact higher crop prices have on agricultural policy and the resulting impact on land use.

We examine data on land use transitions across the United States from the National Resources Inventory (NRI) to show that the government exerts substantial influence on cropland area through the Conservation Reserve Program (CRP). The CRP idles 9\% of cropland area in the United States and has an especially large influence on total cropland area by affecting land use at the margin of economic adjustment. Furthermore, the government alters CRP acreage in response to market conditions - the government decreases cropland area when prices are low and increases cropland area when prices are high. One potential reason for this government response is to achieve the supply management objective of increasing crop prices when prices are low. The expansion of cropland area during high prices may occur because farmers have less political power during high prices or because price stabilization is an objective of the program. It should come as no surprise that CRP may be used for supply

\footnotetext{
${ }^{1}$ Source: Clayton (2016)
} 
management objectives since this was explicitly listed as an objective when the program was introduced (Reichelderfer and Boggess 1988) and continues the legacy of set-aside programs in place before the 1996 Farm Bill (Gardner 2002). Another potential reason that the government changes CRP area in response to market conditions is that farm bills face budget constraints and it is politically attractive to reallocate the limited budget from retiring land to other farm bill programs when crop prices are high.

Economic models of changes in cropland acreage assume land use decisions are made by profit-maximizing farmers that compare the returns from alternative land uses (Lubowski, Plantinga, and Stavins 2008; Langpap and Wu 2011; Barr et al. 2011; Roberts and Schlenker 2013; Hendricks et al. 2014; Lawler et al. 2014). However, we show that government policy plays a major role in determining the amount of CRP acreage enrolled by adjusting the enrollment cap on CRP acreage in the farm bill and by defining the maximum bids for CRP enrollment. One implication of our results is that integrated assessment models of land use change (see Plantinga (2015) for a review) could incorporate government policy changes in response to markets in addition to farmers' response to markets.

We do not argue with the assertion that ethanol production has resulted in an expansion in cropland, but our analysis indicates that the mechanism is more complex than often appreciated. The typical analysis suggests that higher crop prices due to ethanol make crop production relatively more profitable so profit-maximizing farmers expand cropland area (e.g., Roberts and Schlenker 2013; Wright 2015). Our analysis suggests the following story instead. An increase in crop prices resulted in part from an expansion in ethanol production mandated by the the Renewable Fuels Standard (Carter, Rausser, and Smith 2016), and the increase in crop prices led the government to reduce CRP acreage through the enrollment cap in the farm bill which led to an expansion in cropland area. ${ }^{2}$ The increase in cropland

\footnotetext{
${ }^{2}$ However, it is important to note that the expansion in ethanol production cannot explain all of the increase in crop prices (Carter, Rausser, and Smith 2016).
} 
area may have been dramatically smaller - or even a slight decrease in cropland area - if the government had not decreased the CRP enrollment cap in the 2008 and 2014 Farm Bills. ${ }^{3}$

We begin the paper by providing background on CRP and how the program is managed. We then compare changes in cropland conversions with alternative data sources. We then use the National Resources Inventory to show that changes in CRP are the main driver of cropland conversion and that cropland conversion are spatially concentrated. Next, we examine the history of CRP enrolled acres, the enrollment cap, expenditures, and crop prices to show how the government changes CRP area in response to changes in prices. Finally, we estimate the impact on crop prices from different scenarios of changes in CRP enrollment.

\section{Background on CRP}

There are two types of CRP enrollment: general signup and continuous signup (Hellerstein 2017). ${ }^{4}$ For the general signup, any parcel of land in crop production can be offered for CRP enrollment. ${ }^{5}$ The farmer submits a bid to enroll a parcel in a 10- or 15-year contract. FSA sets the maximumm amount the farmer can bid, referred to as the Soil Rental Rate (SRR). Each parcel has an associated Environmental Benefits Index (EBI) that assigns points to wildlife habitat, water quality, erosion control, likelihood of the practice to continue after the contract period, and air quality. The EBI also includes a cost factor-lower bids increase the EBI. After all of the bids have been submitted, FSA accepts offers by determining a cutoff for the EBI at the national level. FSA determines when general signups occur and they may not occur every year.

CRP under the continuous signup can be enrolled at any time. FSA announces specific initiatives for continuous enrollment - such as upland bird habitat nesting, bottomland hardwood, and floodplain wetlands restoration. If parcels meet the eligibility criteria for

\footnotetext{
${ }^{3}$ This implicit link between biofuels and CRP policies is different than the explicit link considered in scenarios by Clark et al. (2013).

${ }^{4}$ See Hellerstein (2017) for a more detailed background on CRP.

${ }^{5} \mathrm{CRP}$ Grasslands seeks to enhance environmental benefits on existing grassland, but this is a relatively small program within CRP. Most CRP seeks to remove land from crop production.
} 
continuous CRP, then they are automatically enrolled if the farmer chooses to participate. That is, continuous CRP does not have a competitive bidding mechanism. The rental rate for continuous signup is generally the SRR or larger (Hellerstein 2017). Continuous CRP has become a more prominent component over time-beginning in 1996 and representing roughly $15 \%$ of 2010 enrollment and $31 \%$ of 2016 enrollment.

The U.S. government influences the number of acres enrolled in CRP through three mechanisms. First, each Farm Bill establishes a cap on the number of acres that can be enrolled in CRP for future years. The Farm Service Agency (FSA) administers the program and determines which parcels are enrolled, but the total acreage FSA enrolls must be less than the cap. Legislation only defines a cap on acreage and does not define a budget limit.

Second, FSA defines the method used to establish SRRs that affect farmer willingness to participate in the program. Currently, FSA determines the SRR by using estimates of county-level nonirrigated cash rental rates and adjusting for specific parcels based on soil quality. However, legislation does not define a maximum budget, so rental rates could be increased to maintain enrollment during times of high commodity prices (Hellerstein and Malcolm 2011).

Third, FSA decides whether or not to issue a general signup and decides the number of acres to accept from the offers of the general signup. The number of acres enrolled in CRP is less than the acreage cap because administrators need to allow opportunity for enrollment in continuous signup (Hellerstein 2017). Another reason CRP enrollment is below the acreage cap is that FSA administrators may think that EBI scores are relatively low in a particular signup period and want to keep acreage well below the cap if they think future offers may have a higher EBI. FSA also affects the acreage enrollment by defining continuous signup initiatives and acreage targets for each initiative. 


\section{Comparison of Land Use Change Between Data Sources}

Next, we compare cropland conversions with alternative datasets. It is important to recognize what each dataset measures and potential reliability issues because interest groups may simply cite the data source that supports their viewpoint. Table 1 reports the main data sources for changes in cropland area in the United States and reports their spatial resolution and definition of "cropland."

We use cropland used for crops from the Census of Agriculture in this paper which is defined as the sum of cropland harvested, failed, and fallowed. Cropland used for crops excludes other pasture and grazing land that could have been used without additional improvements and idle cropland, where idle cropland includes land in CRP. The "total cropland" category in the Census includes these additional categories and thus transitions between CRP and crop production are not reflected as changes in total cropland. The NASS survey does not officially report an estimate of cropland but one can construct such an estimate by simply adding the planted acres across crops and we choose to also include acres harvested of hay. ${ }^{6}$ The Census and NASS survey are available at the county level, however, NASS often does not report certain variables for a county — such as failed acres or acres planted to a particular crop - if it could reveal information of an individual producer or there is insufficient survey response.

The National Resources Inventory (NRI) are assembled by Natural Resources Conservation Service (NRCS) within the USDA. Cropland in the NRI includes pastureland that rotates with crop production, but CRP is a separate land use category. Data for the NRI are collected for points within a sample of segments. Segments are usually half-mile square parcels and there are typically 2 to 3 points within each segment. Data are collected on over 300,000 segments and 800,000 sample points. For each point, NRCS staff manually interpret high-resolution imagery of the land cover and also utilize records from NRCS field offices

\footnotetext{
${ }^{6}$ Since hay is a perennial crop, it is better to use harvested acres of hay rather than planted acres. For annual crops, it is better to use planted acres to include land with failed crop production.
} 


\section{Table 1: Comparison of Data Sources for Changes in Cropland Area}

\begin{tabular}{|c|c|c|}
\hline Data Source & Spatial Resolution & Cropland Definition \\
\hline Census of Agriculture & County & $\begin{array}{l}\text { Harvested cropland plus failed cropland } \\
\text { plus fallowed cropland. }\end{array}$ \\
\hline NASS Survey & County & $\begin{array}{l}\text { The sum of planted acreage of field } \\
\text { crops (barley, beans, canola, corn, cotton, } \\
\text { flax seed, lentils, millet, mustard, oats, } \\
\text { peanuts, rape seed, rice, rye, safflower, } \\
\text { sorghum, soybeans, sugar beets, sunflower, } \\
\text { peas, spring wheat, and winter wheat) plus } \\
\text { harvested acreage of hay. }\end{array}$ \\
\hline $\begin{array}{l}\text { National Resources In- } \\
\text { ventory }\end{array}$ & Point & $\begin{array}{l}\text { Area used for the production of crops } \\
\text { including pastureland in rotation with } \\
\text { crops, permanent hayland, and horticul- } \\
\text { tural cropland. }\end{array}$ \\
\hline Cropland Data Layer & 30 meters & Classification of land cover as a crop. \\
\hline $\begin{array}{l}\text { National Land Cover } \\
\text { Database }\end{array}$ & 30 meters & $\begin{array}{l}\text { Classification of an area used for the pro- } \\
\text { duction of annual crops, orchards, vine- } \\
\text { yards, or actively tilled. }\end{array}$ \\
\hline
\end{tabular}


on cropping history and participation in programs. Data on CRP enrollment for each point are obtained from administrative data. State-level NRI data are available on the NRCS website for the area of each land use and transitions between land uses. ${ }^{7}$ For this paper, we obtained by the point-level data by contacting NRCS staff. The point-level data have been used in several previous economic studies of land use change (e.g., Wu et al. 2004; Lubowski, Plantinga, and Stavins 2006, 2008; Langpap and Wu 2011; Claassen, Langpap, and $\mathrm{Wu} 2016)$.

The Cropland Data Layer (CDL) and National Land Cover Database (NLCD) are remote sensing data products. Remote sensing data are subject to classification errors, so areas classified as a transition between crop production and another land cover may simply arise from classification error. However, remote sensing may also capture other types of transitions not reflected in other data sources. For example, if a low area in a field is too wet to plant in a particular year, then remote sensing may classify this as a transition from cropland to noncropland, but the farmer may still report this area as cropland for the Census.

Figure 1 reports the change in cropland acreage in the United States from 1982 to 2012 according to the Census, NRI, and NASS survey data. There are substantial discrepancies in estimates of the change in cropland acreage since 1982 - a 19 million acre decrease (5\%) according to the Census, a 58 million acre decrease (14\%) according to the NRI, and a 42 million acre decrease (11\%) according to NASS crop acreage data. There are also discrepancies in the amount of cropland expansion from 2007 to 2012 - a 7.8 million acre increase according to the Census versus a 3.9 million acre increase according the NRI. The discrepancies between data sources may arise due to differences in the definition of cropland.

Data from NASS crop acreage estimates seem problematic for estimating changes in cropland acreage - at least in the short run. For example, the NASS data indicate a reduction in cropland of 11.7 million acres from 2008 to 2011 - a time when crop prices remained relatively high and CRP acreage decreased by 3.5 million acres. This should give caution to

\footnotetext{
${ }^{7}$ State-level data are available at https://www.nrcs.usda.gov/wps/portal/nrcs/main/national/ technical/nra/nri/.
} 


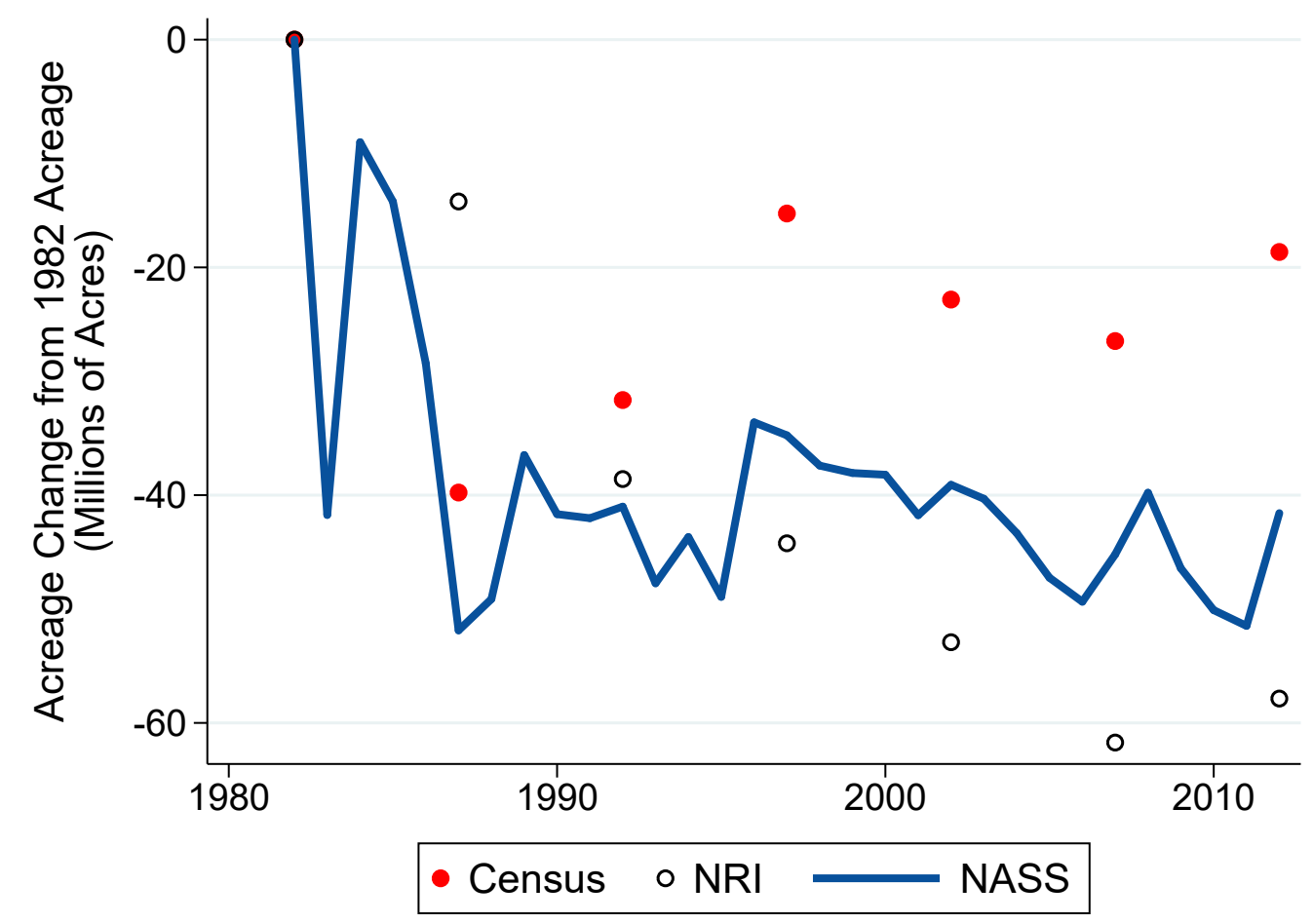

Figure 1: Change in cropland acreage by different data sources

the use of NASS crop acreage data for measuring short-run changes in cropland area as in Barr et al. (2011).

An alternative to these traditional data sources is to use remote sensing data from the CDL or NLCD. In the supplementary appendix, we show widely varying estimates of cropland conversions from previous literature that use remote sensing data. Lark et al. (2017) show that the raw CDL has a bias towards cropland expansion due to improved accuracy of the CDL over time. However, Lark et al. (2017) provide an important contribution by identifying the source of potential issues with using the raw CDL and proposing a set of recommended practices to measure land use change with the CDL. Remote sensing data are advantageous because they are available on a more frequent time scale than the NRI so they have the potential to provide more timely answers to important policy questions. Remote sensing data also provide more detailed and comprehensive information on the location of 
land use transitions which can provide new insights into the underlying causes of land use change and the environmental consequences.

For the purposes of this paper, we prefer to use the NRI data. We use the NRI data instead of the Census because the NRI tracks actual land use transitions rather than just aggregate acreage. Thus, the NRI allows us to assess the previous land use of land converted to cropland. Remote sensing data would also allow us to assess land use transitions, but remote sensing cannot distinguish between pasture and CRP. This distinction is important for understanding the underlying causes of changes in cropland area since different factors drive the conversion of pasture versus CRP. The remainder of our paper uses NRI data to examine the role of government policy, through CRP, in altering cropland area.

\section{CRP is the Main Driver of Cropland Conversion}

Figure 2a displays data on transitions between cropland and other land uses between 2007 and 2012 from the National Resources Inventory. ${ }^{8}$ Panel (a) shows transitions between cropland and other land uses. The top bar shows the gross increase in cropland and the bottom bar shows the gross decrease in cropland. Taking the difference indicates the net change in cropland area. Panel (b) shows transitions between CRP and other land uses.

Although, CRP only accounts for about half of the gross increase in cropland area between 2007 and 2012, it accounts for all of the net increase (figure 2a). A total of 11.1 million acres transitioned to cropland, but 7.2 million acres transitioned from cropland to other uses resulting in a net increase in cropland of 3.9 million acres. The net increase in cropland due to CRP was 4.7 million acres, which is actually larger than the overall net increase in cropland area because some cropland transitioned to developed and other uses. On net, there was little change in cropland area due to conversions of pasture and range. Importantly, figure

\footnotetext{
${ }^{8}$ Supplementary figure A1 shows changes in land use for each category in the Census in recent years and illustrates the challenge of using Census data to estimate the source of land for cropland expansion since the Census changed the definition of pasture between Census years (Nickerson et al. 2011).
} 
2a suggests that cropland area in the United States may have decreased from 2007 to 2012 if government policy had held CRP area constant. ${ }^{9}$

We also examined the history of land use for grassland that transitioned to cropland. Of the pasture and range that transitioned to cropland between 2007 and 2012, forty-eight percent of the land had never been classified as cropland going back to 1982 when the NRI began. This statistic provides validation for concerns about virgin grasslands being converted to cropland. But clearly the main source of cropland expansion was land exiting CRP.

Figure 2b displays data on transitions between CRP and other land uses from 2007 to 2012. While 9.2 million acres transitioned from CRP to other land uses, only about $60 \%$ of this gross loss in CRP acreage transitioned to cropland. There are at least two explanations why exiting CRP does not all return to cropland: (i) conversion costs associated with transitioning the land to crop production and uncertainty about future returns create an incentive to delay a transition (Roberts and Lubowski 2007) and (ii) some of the farmers that entered CRP would have retired land from crop production even in the absence of CRP payments (Lubowski, Plantinga, and Stavins 2008). Another factor is that the NRI only reports general signup $\mathrm{CRP}$ in the $\mathrm{CRP}$ land use category, so some of the land that exited general signup may have enrolled in continuous CRP. A small amount of land transitioned from other uses to CRP and $81 \%$ of the land that entered CRP transitioned from cropland, which is not surprising since CRP enrollment usually requires the land to be retired from crop production.

The NRI indicates a slightly greater proportion of exiting CRP transitioned to crop production than Morefield et al. (2016). Morefield et al. (2016) used CDL crop classifications on exiting CRP parcels and found that 30\% transitioned to crop production. Morefield et al. (2016) suggest their estimate may be lower because the NRI cropland classification includes hay. Using the point-level NRI data we find that $26.4 \%$ of exiting CRP transitioned to hay

\footnotetext{
${ }^{9}$ Though we cannot say for certain because cropland transitions with pasture or range may have been different if CRP acreage had stayed constant.
} 


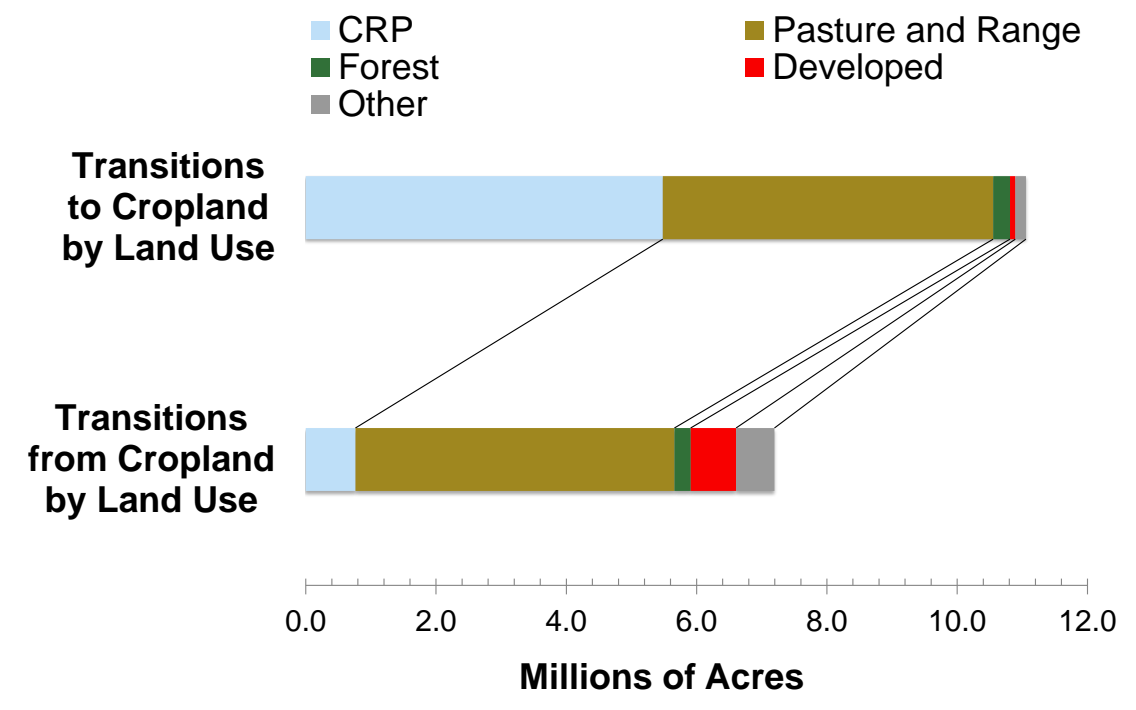

(a) Land Use Transitions with Cropland

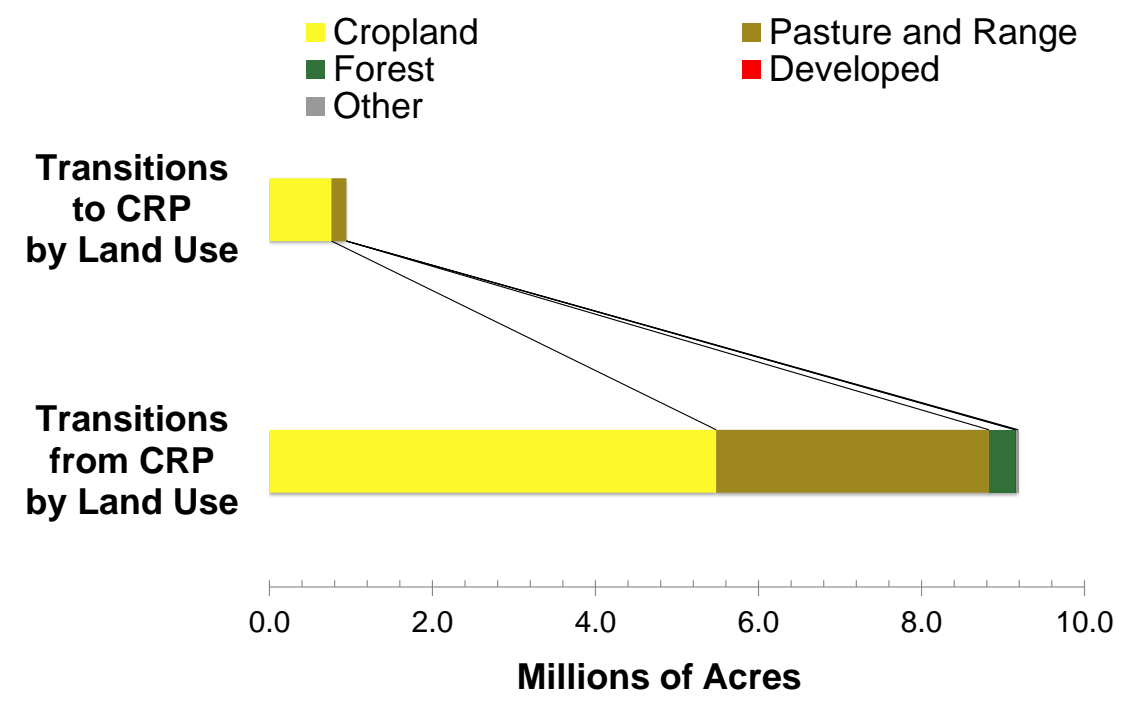

(b) Land Use Transitions with CRP

Figure 2: Land use transitions with cropland and CRP from 2007 to 2012. 
or idle cropland (supplementary table A2), so the NRI indicates roughly $44.2 \%(0.60 \times(1-$ 0.264)) of exiting CRP transitioned to field crop production.

Figure 3 shows the net transitions of cropland with CRP, other land uses, and the overall net change in cropland since 1982 from the National Resources Inventory. The net transition with CRP is calculated as the gross increase in cropland from CRP minus the gross decrease in cropland to CRP, and similarly for other land uses. Figure 3 indicates that most of the variability in cropland area since 1982 has been due to changes in CRP area. While net transitions with other land uses are relatively stable over time, net transitions with CRP vary substantially - the variance of net transitions with CRP is over 11 times larger than the variance of net transitions with other land uses. ${ }^{10}$ Therefore, the deviation of cropland area from its downward trend is mostly due to transitions with CRP.

\section{Changes in Cropland Vary Spatially}

It is also important to recognize that changes in cropland area are spatially concentrated. We aggregated the point-level data from the NRI to the crop-reporting district level in order to visualize how changes in cropland area vary across the U.S. ${ }^{11}$ The top panel of figure 4 shows the net change in cropland area from 2007 to 2012. The bottom left panel shows the net change in cropland area due to transitions with CRP. The bottom right panel shows the net change in cropland area due to transitions with pasture or range. The sum of the net change in cropland in the bottom two maps is similar to the overall net change in cropland since the majority of cropland transitions occur with CRP, pasture, or range (figure 2a).

Figure 4 shows that the largest increases in cropland area between 2007 and 2012 occurred in the Western Corn Belt and Northern Plains while cropland area decreased in Texas

\footnotetext{
${ }^{10}$ The total variance in net changes in cropland area depends on the variance of net changes with CRP, the variance of net changes with other uses, and the covariance between the net changes. The covariance is negative but relatively small so that most of the variance in net changes in cropland is dominated by the variance of net changes with CRP.

${ }^{11}$ There are not enough points in each county to accurately map land use change by county.
} 


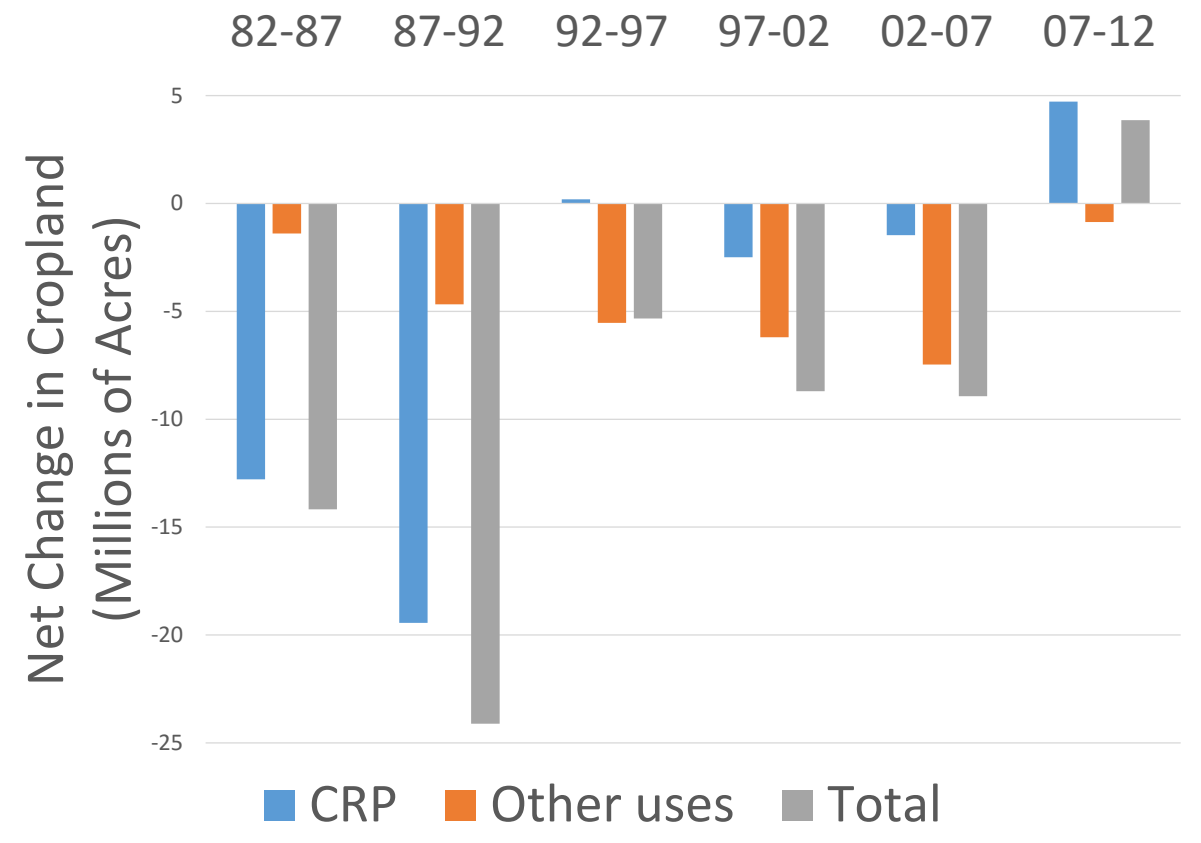

Figure 3: Net transitions of cropland with CRP and other land uses. 

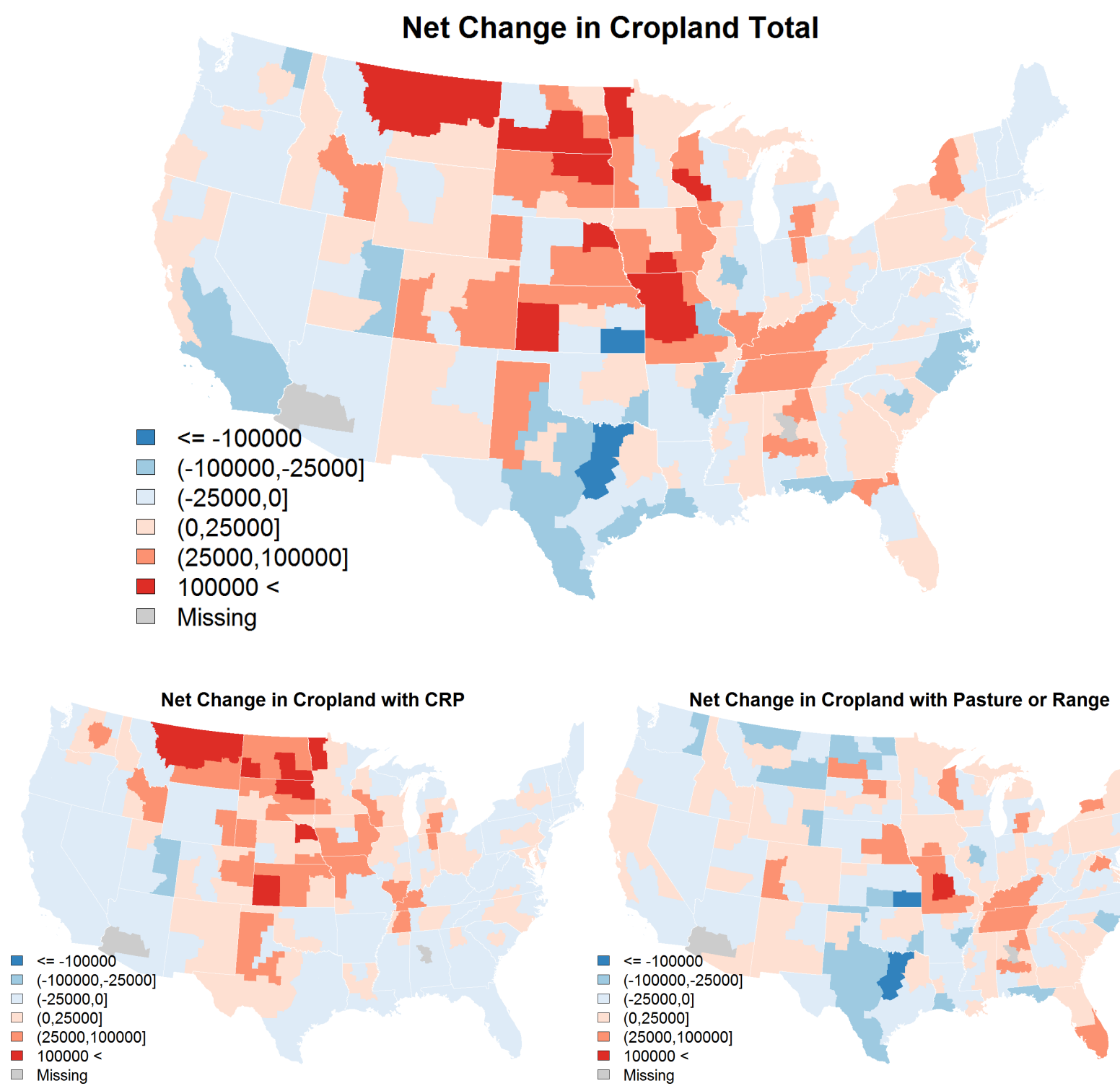

Figure 4: Net change in cropland acres by crop reporting district 2007-2012 
and California. ${ }^{12}$ Not surprisingly, the pattern of overall net increases in cropland area corresponds closely with the net changes due to transitions with CRP. Net conversions of pasture or range to cropland occurred mostly in Missouri, Southern Iowa, and eastern Nebraska. Most of the Plains experienced net decreases in cropland area due to transitions with pasture or range, or small net increases. The net decrease in cropland in Texas occurred mostly due to transitions with pasture or range.

Figures A2-A6 in the supplementary appendix show maps of net changes in cropland area for each five-year period between 1982 and 2007. A few observations are worth noting. First, there was actually a greater expansion of cropland due to losses of pasture or range in the Plains states in the periods 1982-1987 and 1992-1997 than in the more recent period of 2007-2012. Second, there were large reductions in cropland after the CRP began in 1986 across most of the U.S. in the period 1987-1992, but especially concentrated in the Plains states. Last, there have been net reductions in cropland due to transitions with pasture or range in the South, but not in the North, consistently across every period .

\footnotetext{
${ }^{12}$ The map in figure 4 is similar to the results in Lark, Salmon, and Gibbs (2015). Two differences are that our map seems to indicate greater cropland expansion in Montana and their map appears to indicate a net expansion in Central Texas whereas ours indicates a net reduction.
} 


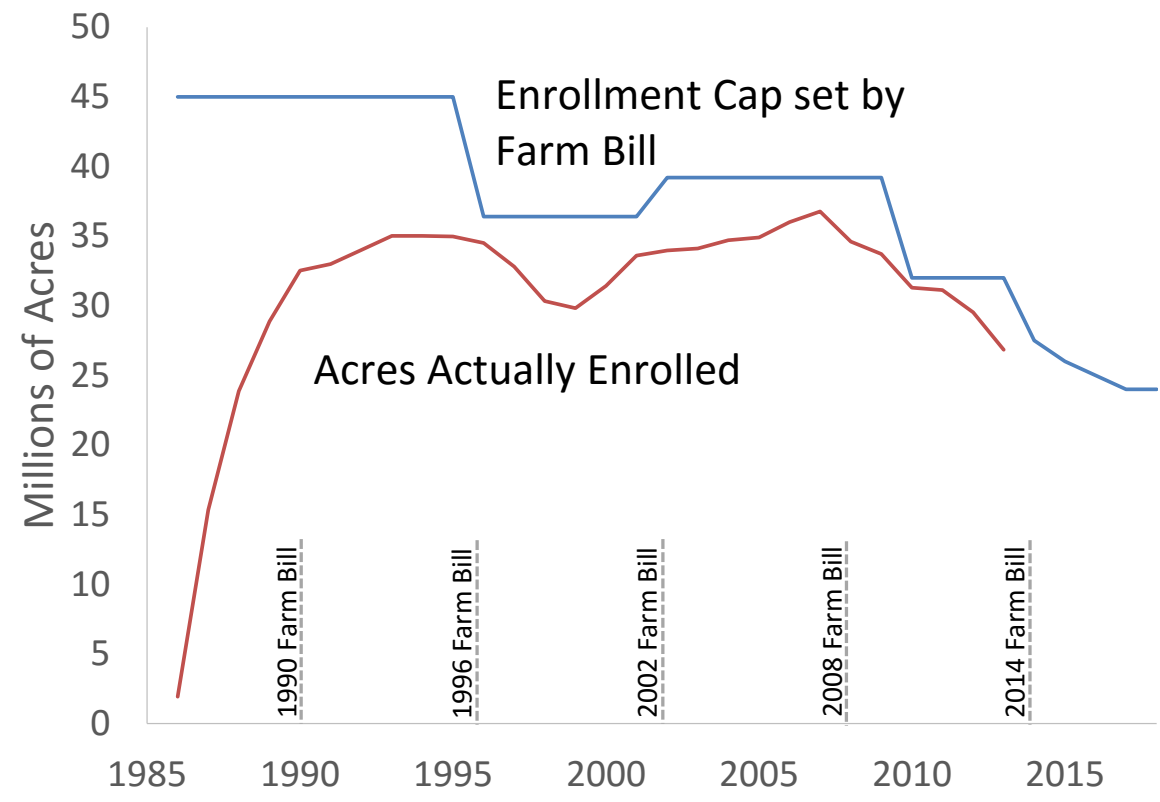

Figure 5: The CRP enrollment cap and actual acres enrolled. CRP enrollment cap data are obtained directly from the text of legislation from each Farm Bill. CRP enrolled acreage data are obtained from the Farm Service Agency.

\section{Government Influence on CRP Area}

The preceding examination of the data indicates that the change in CRP is the main driver of change in cropland area in the United States. Next, we show that changes in CRP area are heavily influenced by government policy that responds to market prices.

The enrollment cap set by the Farm Bill represents a key mechanism for the government to alter CRP acreage independent of farmer enrollment demand. Figure 5 shows that the enrollment cap and acres enrolled in CRP move closely together. Since enrollment is never equal to the enrollment cap, it may appear that the enrollment cap is not binding and has no effect on enrolled acreage. However, as discussed in the section on the background of CRP, FSA administrators keep enrollment below the enrollment cap to leave opportunity for continuous CRP enrollment.

Furthermore, examining the history of the general signup indicates that FSA could have enrolled more acres if the enrollment cap were larger. Following the decrease in the enrollment 
Table 2: Summary of Farm Bills, Prices, and Changes in CRP

\begin{tabular}{lccc}
\hline Farm Bill & Crop Prices & $\begin{array}{c}\text { Change in } \\
\text { Enrollment Cap }\end{array}$ & $\begin{array}{c}\text { Change in } \\
\text { CRP Expenditures }\end{array}$ \\
\hline 1990 & Average & Maintain & Increase \\
1996 & High & Decrease & Decrease \\
2002 & Low & Increase & Increase \\
2008 & High & Decrease & Decrease \\
2014 & High & Decrease & Decrease \\
\hline
\end{tabular}

cap in 1996, FSA only accepted 60-70\% of offered acres (Hellerstein 2017). After the 2008 Farm Bill decreased the enrollment cap, FSA did not hold a general signup until fiscal year 2011 contracts. FSA did not hold a general signup for contracts again in fiscal year 2015 and the acceptance rate for fiscal year 2016 was merely 22\% (Farm Service Agency 2016). And even though CRP is subject to 10-15 year contracts, the government increased the speed of acreage adjustment by allowing the early release from contracts in 1995, 1996, and 2015 (Stubbs 2014). The close relationship between the cap and enrolled acreage (figure 5) and knowledge about the how the CRP is administered indicate that the government plays an important role in adjusting CRP acreage over time.

Table 2 summarizes the perception about commodity prices, the change in the CRP enrollment cap, and the change in CRP expenditures for each farm bill since CRP began (see figures A7 and A8 in the supplementary appendix for prices and CRP expenditures over time). The enrollment cap and total expenditures for CRP declined in the late 1990s following high crop prices. Then the enrollment cap and total expenditures increased in the early 2000s when crop prices were low. When crop prices increased in 2008 and subsequent years, the government did not adjust expenditures to maintain acreage in CRP. Instead, CRP expenditures decreased by about $\$ 0.2$ billion from 2008 to 2015 and the government dramatically decreased the enrollment cap. Commodity prices have fallen in recent years and current policy discussions create an expectation that the next farm bill will increase the enrollment cap (Forman-Cook 2016; Newton 2017). This illustrates that the government increases CRP area when prices are low and decreases CRP area when prices are high. 
Two key motivations for the government to alter CRP acreage as crop prices change are to achieve supply management objectives and for budgetary reasons. First, the U.S. government may alter CRP area in a way that distorts markets for supply management objectives by removing more cropland from production when prices are low in order to increase crop prices. While farmers benefit from incentivized reductions in supply whether prices are high or low, there are a couple reasons why optimal supply reductions change with market prices. First, the politically optimal policy likely changes with market prices. Rausser (1992, p. 137) argues the following regarding soil conservation policies:

"In times of high agricultural supply and low prices, political opposition to supply-control policies can be countered when these policies are masked by conservation policies. When markets are expanding and prices are high, however, the public will not compensate farmers sufficiently to hold land out of production."

Another political factor is the influence of agricultural input suppliers. In times of low prices, the interest of farmers dominates to reduce production but input suppliers have greater influence when prices are high to expand production. The second reason optimal supply reductions change with prices is because the objective of policy may be, at least in part, to stabilize prices (Wright 1979; Wright and Williams 1988; Innes 1990).

Another motivation for the government to alter CRP acreage as crop prices change is due to budgetary reasons. The Congressional Budget Office (CBO) releases an estimate of spending for 10 years in the future assuming the old farm bill programs are maintained. This projection of spending, known as the CBO baseline, is the key number that establishes funding available for the new farm bill (Coppess 2017). Congress then decides how to allocate money to different farm bill programs, including CRP, to stay within the CBO baseline. When crop prices were high in the 2008 and 2014 Farm Bills, legislators could have maintained the CRP enrollment cap and FSA administrators could have increased Soil Rental Rates in order to incentivize farmers to maintain acres enrolled in CRP. However, 
the additional funding for CRP would have had to come at the expense of other farm bill programs to keep projected spending within the CBO baseline.

In 2008 and 2014, reducing the CRP enrollment cap may have been a politically attractive means to allocate the budget to other popular programs. Thus, Rausser's (1992) political economy argument above could be modified to account for the effect of the CBO baseline. In times of low prices, spending on voluntary land retirement programs is more politically appealing because it has a smaller impact on the overall budget. In times of high prices, reductions in voluntary land retirement programs are more politically appealing because it provides savings in projected budgetary expenditures that can be allocated to other farm bill programs. It is also important to note that Congress has not chosen to maintain CRP expenditures over time. Instead, table 2 shows that expenditures tend to actually decrease during times of high crop prices.

\section{The Impact of Changes in CRP Area on Production and Prices}

Next, we estimate the impact of changes in CRP area on crop production and prices under two scenarios. Our first scenario examines the impact of reducing CRP acreage by 12.8 million acres as is projected to occur from 2007 to 2017 according to the cap set in the 2014 Farm Bill. Our second scenario examines the impact of increasing CRP acreage by 12.8 million acres. The second scenario is relevant given the recently low crop prices and pressure by farm groups to increase CRP acreage in the next farm bill. We estimate the impacts on corn, soybeans, and wheat since most CRP land transitions with these three crops (supplementary table A2).

We calculate the percent change in production for crop $c$ as

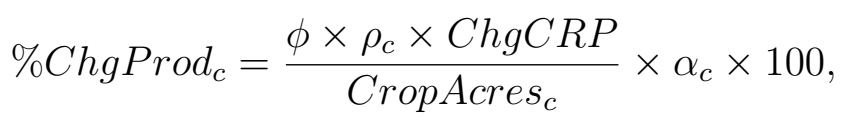


where $\phi$ is the proportion of land exiting (entering) CRP that transitions to (from) cropland, $\rho_{c}$ is the share of transitioning cropland represented by crop $c, C h g C R P$ is the change in $\mathrm{CRP}$ acres in the respective scenario, $\mathrm{CropAcres}_{c}$ is the original total acres of crop $c$, and $\alpha_{c}$ is the yield of cropland that transitions with CRP relative to average cropland. We assume that $60 \%$ of $\mathrm{CRP}$ acreage returns to cropland when the government is reducing CRP acreage but that $81 \%$ of CRP acreage transitions from cropland when the government increases CRP acreage based on transitions between 2007 and 2012 from the NRI $(\phi)$. Based on supplementary table A2, we assume that $23.0 \%$ of transitioning cropland produces corn, $20.4 \%$ soybeans, and $18.4 \%$ wheat $\left(\rho_{c}\right)$. We calculate the change in crop acreage relative to the 2001-2015 average acreage for the respective crop $\left(\right.$ CropAcres $\left._{c}\right)$. In order to translate the relative change in acreage into a relative change in production, we account for the fact that CRP land tends to be of lower quality.

We assume that a $1 \%$ increase in crop acreage due to changes in CRP acreage increases production by $0.88 \%, 0.90 \%$, and $0.94 \%$ for corn, soybeans, and wheat $\left(\alpha_{c}\right) .{ }^{13}$ We derive these numbers by first accounting for the fact that CRP transitions occur in districts with yields below the national average. We calculate the number of acres in each district that converted from CRP to each crop between 2007 and 2012 according to the NRI. Then we multiply this times the 2001-2010 average yield in the district and then calculate the nationallevel production and yield for land that exited CRP. We find that the national-level yield of land that exited CRP is $93 \%, 94 \%$, and $100 \%$ the magnitude of the overall national-level yield for corn, soybeans, and wheat. However, it is also the case that the land within each district that converted from CRP to crop production is less productive relative to the district average. Lubowski et al. (2006) estimates that potential yields for CRP land are 95\%, 96\%, and $94 \%$ of the potential yield for cropland within a district for corn, soybeans, and wheat.

\footnotetext{
${ }^{13}$ The difference in expected yields between cropland and CRP may seem small, but may reflect the fact that the majority of CRP acres are owned by retired farmers or those who identified something other than farming as their primary occupations (Sullivan et al. 2004). Therefore, some CRP enrollment is driven by factors other than the relatively low productivity of the land.
} 
Multiplying the estimates of the yield gap for districts with CRP conversions relative to the nation and the yield gap within districts gives our estimate of the $\alpha_{c}$ parameters.

According to the assumptions in the previous paragraphs, the projected decrease in CRP acreage from 2007 to 2017 results in a $1.8 \%$ increase in corn production, $1.9 \%$ increase in soybean production, and $2.3 \%$ increase in wheat production for the United States. Adjemian and Smith (2012) estimate that a 1\% increase in U.S. corn (soybeans) supply decreases the price of corn (soybeans) by $4.91 \%$ (2.91\%) with recent ethanol usage. We also use the $95 \%$ confidence intervals of the Adjemian and Smith (2012) estimates to construct $95 \%$ confidence intervals for price impacts of changes in CRP acreage. The estimates of Adjemian and Smith (2012) imply that the decrease in CRP acreage decreases the price of corn by $8.9 \%$ with a $95 \%$ confidence interval of $(-11.7 \%,-6.0 \%)$ and the price of soybeans by $5.4 \%$ with a $95 \%$ confidence interval of $(-9.2 \%,-1.7 \%)$. Looking forward, CRP acreage is likely to increase in the next farm bill. Increasing CRP acreage back to 2007 levels would decrease production by $2.4 \%$ for corn, $2.5 \%$ for soybeans, and $3.1 \%$ for wheat. Corn prices would thus increase by $12.0 \%$ with a $95 \%$ confidence interval of $(8.1 \%, 15.8 \%)$ and soybean prices would increase by $7.3 \%$ with a $95 \%$ confidence interval of $(2.3 \%, 12.4 \%)$. These price impacts are larger than would have occurred prior to the ethanol boom (Adjemian and Smith 2012).

Unfortunately, we do not have price flexibility estimates for wheat to estimate the price impact for wheat. However, the price impact is likely smaller for wheat than for corn or soybeans - even though the impact on U.S. production is larger. The U.S. only represents $9 \%$ of global production for wheat compared to roughly $40 \%$ of global production for corn and soybeans.

\section{Conclusion}

Area in CRP is projected to decrease by 12.8 million acres from 2007 to 2017 in response to high crop prices around the time of the 2014 Farm Bill. Assuming that $60 \%$ of this land enters cropland as it did between 2007 and 2012, then this change in agricultural policy 
alone results in an expansion of cropland by 7.68 million acres. By late 2016, crop prices fell dramatically and discussion about the next farm bill already indicated that an expansion of CRP acreage was likely (Forman-Cook 2016).

While CRP provides a mechanism to reduce the negative externalities from crop production, it can also serve as a politically popular form of supply management. Previous research has shown that paid land diversions can be part of an optimal mix of policy mechanisms to achieve political goals of providing economic transfers to certain types of farmer (Chambers 1992; Bourgeon and Chambers 2000). However, adjusting CRP area in response to market conditions is not likely optimal from an environmental perspective if negative environmental impacts occur due to land conversions and not simply the aggregate amount of cropland. An important topic for future research is to understand the relative environmental impact from short-term land retirement (e.g., fallowing or cover crops) versus long-term land retirement (e.g., restoration to native habitat) and the optimal mix of these types of land retirement over time.

Early analysis of the CRP found that contracts were targeted to retire as much land as possible in order to reduce production, rather than achieving environmental benefits (Reichelderfer and Boggess 1988). Reforms to CRP over time have improved spatial targeting to achieve environmental benefits. Our analysis shows that the government has adjusted CRP acreage over time in response to changes in market conditions. The effectiveness of the supply management aspect of CRP is questionable since the farm bill sets the enrollment cap several years in advance of when market conditions are unknown. For example, the decrease in CRP mandated by the 2014 Farm Bill has put even greater downward pressure on recent crop prices - and, ironically, increased government expenditures through traditional commodity programs which are triggered at low prices. Future reforms could optimally adjust CRP acreage over time to achieve environmental objectives, while still allowing market responses to changes in demand. 
The government's role in determining total cropland area through CRP has important implications for food and environmental security. If crop prices increase in the future due to increased demand for meat and dairy products or climate change, then the supply response through cropland expansion depends largely on agricultural policy. Therefore, environmental impacts of cropland expansion depend on the magnitude and targeting of cropland expansion by agricultural policy. 


\section{References}

Adjemian, M.K., and A. Smith. 2012. "Using USDA Forecasts to Estimate the Price Flexibility of Demand for Agricultural Commodities." American Journal of Agricultural Economics 94:978-995.

Barr, K.J., B.A. Babcock, M.A. Carriquiry, A.M. Nassar, and L. Harfuch. 2011. "Agricultural Land Elasticities in the United States and Brazil." Applied Economic Perspectives and Policy 33:449-462.

Bourgeon, J.M., and R.G. Chambers. 2000. "Stop-and-Go Agricultural Policies." American Journal of Agricultural Economics 82:1-13.

Carter, C., G. Rausser, and A. Smith. 2016. "Commodity Storage and the Market Effects of Biofuel Policies." American Journal of Agricultural Economics, pp. 53.

Chambers, R.G. 1992. "On the Design of Agricultural Policy Mechnanisms." American Journal of Agricultural Economics 74:646-654.

Claassen, R., C. Langpap, and J. Wu. 2016. "Impacts of Federal Crop Insurance on Land Use and Environmental Quality." American Journal of Agricultural Economics, oct, pp. aaw075.

Clark, C.M., Y. Lin, B.G. Bierwagen, L.M. Eaton, M.H. Langholtz, P.E. Morefield, C.E. Ridley, L. Vimmerstedt, S. Peterson, and B.W. Bush. 2013. "Growing a Sustainable Biofuels Industry: Economics, Environmental Considerations, and the Role of the Conservation Reserve Program." Environmental Research Letters 8:025016.

Clayton, C. 2016. "Looking at a New Safety Net." Available at: https: //www.dtnpf.com/agriculture/web/ag/news/farm-life/article/2016/12/12/ conner-trump-administration-creates. 
Coppess, J. 2017. "CBO Baseline and the Potential for Conflicts by Expanding CRP." Choices $32: 1-8$.

Das, C., W. Capehart, H. Mott, P. Zimmerman, and T. Schumacher. 2004. "Assessing Regional Impacts of Conservation Reserve Program-type Grass Buffer Strips on Sediment Load Reduction from Cultivated Lands." Journal of Soil and Water Conservation 59:134142.

Donner, S.D., and C.J. Kucharik. 2008. "Corn-based Ethanol Production Compromises Goal of Reducing Nitrogen Export by the Mississippi River." Proceedings of the National Academy of Sciences 105:4513-4518.

Fargione, J., J. Hill, D. Tilman, S. Polasky, and P. Hawthorne. 2008. "Land Clearing and the Biofuel Carbon Debt." Science 319:1235-1238.

Farm Service Agency. 2016. "The Conservation Reserve Program: 49th Signup Results." Available at https://www.fsa.usda.gov/Assets/USDA-FSA-Public/usdafiles/ Conservation/PDF/SU49Book_State_final1.pdf.

Forman-Cook, W. 2016. "Vilsack wants more CRP acres in next farm bill." Available at: http://www.agri-pulse.com/ Vilsack-wants-more-CRP-acres-in-next-farm-bill-05052016.asp.

Gardner, B.L. 2002. American Agriculture in the Twentieth Century. Cambridge, MA: Harvard University Press.

Gebhart, D., H. Johnson, H. Mayeux, and H. Polley. 1994. "The CRP Increases Soil Organic Carbon." Journal of Soil and Water Conservation 49:488-492.

Gelfand, I., T. Zenone, P. Jasrotia, J. Chen, S.K. Hamilton, and G.P. Robertson. 2011. "Carbon Debt of Conservation Reserve Program (CRP) Grasslands Converted to Bioenergy Production." Proceedings of the National Academy of Sciences 108:13864-13869. 
Hellerstein, D., and S. Malcolm. 2011. "The Impact of Rising Corn Prices on the Conservation Reserve Program.” Working paper, Economic Research Service, USDA.

Hellerstein, D.M. 2017. "The US Conservation Reserve Program: The Evolution of an Enrollment Mechanism." Land Use Policy 63:601-610.

Hendricks, N.P., S. Sinnathamby, K. Douglas-Mankin, A. Smith, D.A. Sumner, and D.H. Earnhart. 2014. "The Environmental Effects of Crop Price Increases: Nitrogen Losses in the U.S. Corn Belt." Journal of Environmental Economics and Management 68(3):507 526.

Herkert, J.R. 2007. "Conservation Reserve Program Benefits on Henslow's Sparrows Within the United States." Journal of Wildlife Management 71:2749-2751.

Innes, R. 1990. "Uncertainty , Incomplete Markets and Government Farm Programs.” Southern Economic Journal 57:47-65.

Keeler, B.L., and S. Polasky. 2014. "Land-Use Change and Costs to Rural Households: A Case Study in Groundwater Nitrate Contamination." Environmental Research Letters 9:074002.

Langpap, C., and J. Wu. 2011. "Potential Environmental Impacts of Increased Reliance on Corn-Based Bioenergy." Environmental and Resource Economics 49:147-171.

Lark, T.J., R.M. Mueller, D.M. Johnson, and H.K. Gibbs. 2017. "Measuring Land-Use and Land-Cover Change using the U.S. Department of Agriculture's Cropland Data Layer: Cautions and Recommendations." International Journal of Applied Earth Observation and Geoinformation 62:224-235.

Lark, T.J., J.M. Salmon, and H.K. Gibbs. 2015. "Cropland Expansion Outpaces Agricultural and Biofuel Policies in the United States." Environmental Research Letters 10:044003. 
Lawler, J.J., D.J. Lewis, E. Nelson, A.J. Plantinga, S. Polasky, J.C. Withey, D.P. Helmers, S. Martinuzzi, D. Pennington, and V.C. Radeloff. 2014. "Projected Land-Use Change Impacts on Ecosystem Services in the United States." Proceedings of the National Academy of Sciences 111:7492-7497.

Lubowski, R.N., S. Bucholtz, R. Claassen, M.J. Roberts, J.C. Cooper, A. Gueorguieva, and R. Johansson. 2006. "Environmental Effects of Agricultural Land-Use Change." Economic Research Report No. 25, USDA, Economic Research Service.

Lubowski, R.N., A.J. Plantinga, and R.N. Stavins. 2006. "Land-use Change and Carbon Sinks: Econometric Estimation of the Carbon Sequestration Supply Function." Journal of Environmental Economics and Management 51(2):135-152.

- 2008. "What Drives Land-Use Change in the United States? A National Analysis of Landowner Decisions." Land Economics 84:529-550.

Meehan, T.D., A.H. Hurlbert, and C. Gratton. 2010. "Bird Communities in Future Bioenergy Landscapes of the Upper Midwest." Proceedings of the National Academy of Sciences 107:18533-18538.

Morefield, P.E., S.D. LeDuc, C.M. Clark, and R. Iovanna. 2016. "Grasslands, Wetlands, and Agriculture: The Fate of Land Expiring from the Conservation Reserve Program in the Midwestern United States." Environmental Research Letters 11:94005.

Newton, J. 2017. "Change on the Horizon for the Conservation Reserve Program?" Farm Bureau, Market Intel. Available at: https://www.fb.org/market-intel/ change-on-the-horizon-for-the-conservation-reserve-program.

Nickerson, C., R. Ebel, A. Borchers, and F. Carriazo. 2011. Major Uses of Land in the United States, 2007. US Department of Agriculture, Economic Research Service. 
Pimentel, D., C. Harvey, P. Resosudarmo, K. Sinclair, D. Kurz, M. McNair, S. Crist, L. Shpritz, L. Fitton, R. Saffouri, and R. Blair. 1995. "Environmental and Economic Costs of Soil Erosion and Conservation Benefits." Science 267:1117-1123.

Plantinga, A.J. 2015. "Integrating Economic Land-Use and Biophysical Models." Annual Review of Resource Economics 7:233-249.

Rausser, G. 1992. "Predatory Versus Productive Government: The Case of U.S. Agricultural Policies." Journal of Economic Perspective 6:133-157.

Reichelderfer, K., and W.G. Boggess. 1988. "Government Decision Making and Program Performance: The Case of the Conservation Reserve Program." American Journal of Agricultural Economics 70:1-11.

Roberts, M.J., and R.N. Lubowski. 2007. "Enduring Impacts of Land Retirement Policies: Evidence from the Conservation Reserve Program." Land Economics 83:516-538.

Roberts, M.J., and W. Schlenker. 2013. "Identifying Supply and Demand Elasticities of Agricultural Commodities: Implications for the US Ethanol Mandate." American Economic Review 103:2265-2295.

Stubbs, M. 2014. "Conservation Reserve Program (CRP): Status and Issues." Congressional Research Service Report.

Sullivan, P., D. Hellerstein, L. Hansen, R. Johansson, S. Koenig, R. Lubowski, W. Mcbride, D. Mcgranahan, M. Roberts, S. Vogel, and S. Bucholtz. 2004. "The Conservation Reserve Program: Economic Implications for Rural America." Agricultural Economic Report No. 834, Economic Research Service, USDA.

Wright, B.D. 1979. "The Effects of Ideal Production Stabilization: A Welfare Analysis under Rational Behavior." Journal of Political Economy 87:1011-1033. 
Wright, B.D., and J.C. Williams. 1988. "The Incidence of Market-Stabilising Price Support Schemes." The Economic Journal 98:1183-1198.

Wright, C.K. 2015. "US Agricultural Policy, Land Use Change, and Biofuels: Are We Driving our Way to the Next Dust Bowl?" Environmental Research Letters 10:51001.

Wu, J., R.M. Adams, C.L. Kling, and K. Tanaka. 2004. "From Microlevel Decisions to Landscape Changes: An Assessment of Agricultural Conservation Policies." American Journal of Agricultural Economics 86:26-41. 